\title{
Photodynamic Tumor Therapy: Mitochondrial Benzodiazepine Receptors as a Therapeutic Target*
}

\author{
Ajay Verma, ' Stephen L. Facchina, ' David J. Hirsch, ${ }^{2}$ \\ Shi-Yu Song, ${ }^{5}$ Larry F. Dillahey, Jerry R. Williams, ${ }^{5}$ and \\ Solomon H. Snyder $2,3,4$ \\ ${ }^{1}$ Department of Neurology, Uniformed Services University of the \\ Health Sciences, Bethesda, Maryland, U.S.A. \\ Departments of ${ }^{2}$ Neuroscience, ${ }^{3}$ Pharmacology and Molecular \\ Sciences, ${ }^{4}$ Psychiatry, and ${ }^{5}$ Oncology, Johns Hopkins University \\ School of Medicine, Baltimore, Maryland, U.S.A. \\ Communicated by S. H. Snyder. Accepted November 24, 1997.
}

\begin{abstract}
Background: Photodynamic therapy employs photosensitive agents such as porphyrins to treat a variety of tumors accessible to light-emitting probes. This approach capitalizes on the selective retention of porphyrins by cancer cells. Cancer cells also have elevated levels of mitochondrial benzodiazepine receptors which bind porphyrins with high affinity.

Methods: Cultured cancer cell lines were exposed to porphyrin and porphyrin-like compounds and then irradiated with light. Cytotoxicity of this treatment was measured via clonogenic assays. Mitochondrial benzodi-
\end{abstract}

azepine receptor pharmacology was studied using $\left[{ }^{3} \mathrm{H}\right]$ PK11195 binding to cancer cell homogenates and isolated kidney mitochondrial membranes.

Results: We show that therapeutic potencies of porphyrins correlate closely with affinities for mitochondrial benzodiazepine receptors. Sensitivities of tumor cell lines to photodynamic therapy parallel their densities of these receptors.

Conclusion: We propose that porphyrin photodynamic therapy is mediated by mitochondrial benzodiazepine receptors.

\section{Introduction}

Photodynamic therapy (PDT) employs the dyesensitized photooxidation of biological matter to treat various conditions, especially tumors that are accessible to light probes, such as skin, bladder, vaginal, bronchial, and rectal cancers (1-4). Although the molecular mechanism for thera-

\footnotetext{
*The opinions or assertions contained herein are the private views of the authors and are not to be construed as official or as reflecting the views of the Army or the Department of Defense.

Address correspondence and reprint requests to: Dr. Solomon H. Snyder, Department of Neuroscience, Johns Hopkins University School of Medicine, $725 \mathrm{~N}$. Wolfe Street, Baltimore, MD 21205, U.S.A. Phone: 410-955-3024; Fax: 410-955-3623.
}

peutic actions for PDT has not been established, substantial evidence indicates a prominent role for mitochondria. Porphyrins, the class of photosensitive dyes most often employed, tend to concentrate in mitochondria $(5,6)$. Moreover, damage to mitochondrial function is one of the earliest events in porphyrin PDT (7-9). We speculated that mitochondrial benzodiazepine receptors (MBR) might play a role in the mechanism of PDT. MBR are distinct from the neuronal "central" benzodiazepine receptors but can bind clinically employed benzodiazepines with high affinity. MBR are localized to mitochondria where they comprise a complex of an 18 kilodalton $(\mathrm{kD})$ receptor protein, the $32 \mathrm{kD}$ voltage- 
dependent anion carrier (VDAC), and the $30 \mathrm{kD}$ adenine nucleotide carrier (10-14). Porphyrins represent endogenous ligands for MBR. In tissue extracts, porphyrins are the only substances that bind with nanomolar affinity to MBR (15-17). Porphyrin PDT targets mitochondrial membranes where MBR are localized (18). Incubation of isolated mitochondria with porphyrins and light results in the oxidation of sulfhydryl groups in specific membrane proteins with molecular weights similar to MBR constituents (19). Moreover, loss of ATP/ADP exchange via the adenine nucleotide carrier is a major early step in porphyrin photosensitization of isolated mitochondria (20). In the present study, we show that the relative potencies of porphyrins in eliciting photodynamic killing of tumor cells correlate closely with their affinities for MBR. Moreover, the relative sensitivities of tumor cell lines to PDT parallel their MBR levels.

\section{Materials and Methods}

Materials

Cells were obtained from American Tissue Culture Collection (Rockville, MD). $\left[{ }^{3} \mathrm{H}\right]$ PK11195 was obtained from NEN/Dupont (Boston, MA).

Porphyrins were obtained from Porphyrin Products (Logan, UT). PK11195 was a gift from Pharmuka and R05-4864 was a gift from Hoffman-LaRoche. All other chemicals were obtained from Sigma Chemical Co. (St. Louis, MO).

\section{Cell Culture}

Cells were maintained at $37^{\circ} \mathrm{C}$ in a humidified $\mathrm{CO}_{2}$ incubator in the following media: mouse $\mathrm{L}$ cells were grown in MEM plus $10 \%$ horse serum; C6 glioma cells were grown in Ham's F-10 plus $15 \%$ horse serum and $2.5 \%$ fetal bovine serum (FBS); V79 were grown in MEM plus $10 \%$ FBS; HeLa, WiDR, and LS174T cells were grown in MEM plus nonessential amino acids and $10 \%$ FBS; and SVEC 4-10 cells were grown in Dulbecco's modified Eagle's medium (DMEM) (low glucose) plus $10 \%$ FBS. For clonogenic survival experiments, cells were plated at appropriate densities as suspensions approximately $12 \mathrm{hr}$ before drug/light exposure.

\section{MBR Assays}

Rat kidney mitochondria were prepared as described (16). Cell homogenates used for binding studies were prepared by removing culture media, rinsing with phosphate buffered saline (PBS), and homogenizing in $10 \mathrm{mM}$ HEPES ( $\mathrm{pH}$, 7.4) using a Dounce $B$ homogenizer with 10 to 15 strokes at $4^{\circ} \mathrm{C}$. Protein was determined by Coomassie Blue protein assay (BioRad, Hercules, CA) and adjusted to a final value of $0.5 \mathrm{mg} / \mathrm{ml}$ in the binding assay. $\mathrm{IC}_{50}$ and $\mathrm{K}_{\mathrm{i}}$ values for porphyrins and analogs were determined by displacement of $\left[{ }^{3} \mathrm{H}\right]$ PK11195 binding to cell homogenates and isolated rat kidney mitochondria, respectively, as described earlier (16). MBR densities of the various cell lines were determined by performing Scatchard analyses on [ $\left.{ }^{3} \mathrm{H}\right]$ PK1 1195 saturation isotherms for each cell line as reported earlier (16). For $\left[{ }^{3} \mathrm{H}\right]$ PK1 1195 binding studies in live cells, confluent cultures in $60-\mathrm{mm}$ dishes were used. After medium removal and rinsing with PBS, live cell monolayers were incubated in $2 \mathrm{ml}$ PBS containing $2 \mathrm{nM}\left[{ }^{3} \mathrm{H}\right]$ PK11195 with and without $10 \mu \mathrm{M}$ PK11195 or varying concentrations of Photofrin II at $37^{\circ} \mathrm{C}$ for $1 \mathrm{hr}$. Cells were scraped from the dishes, collected over GF/C glass fiber filters, and washed three times with ice-cold PBS. The filters were counted for radioactivity in scintillation cocktail.

\section{Phototoxicity Studies}

All cultured cells were plated at a density of $\mathbf{3 0 0}$ to 10,000 per dish. Cells were exposed to varying concentrations of porphyrins and analogs in DMEM for $4 \mathrm{hr}$. After a brief wash with PBS, cells were irradiated for $60 \mathrm{sec}$ with a broad spectrum light from a Kratos lamp at $60 \mathrm{~cm}$ distance and cultured in DMEM. Clonogenic assessment for cell survival was performed after 7 to 14 days of cell growth. D37 values represent concentrations that reduce survival to $37 \%$ of control.

\section{Results}

To explore a role for MBR in porphyrin phototoxicity we first determined whether V79 cell homogenates display high-affinity $\left[{ }^{3} \mathrm{H}\right] \mathrm{PK} 11195$ binding with an MBR pharmacological profile. [ $\left.{ }^{3} \mathrm{H}\right]$ PK11195 bound to a single site on V79 homogenates with a $\mathrm{Kd}$ of $1.2 \mathrm{nM}$ and $\mathrm{B}_{\max }$ of $3.9 \mathrm{pmol} / \mathrm{mg}$ protein. Binding of $\left.\mathrm{l} n M{ }^{3} \mathrm{H}\right]$ PK1 1195 to V79 homogenates was potently displaced by unlabeled PK11195, R05-4864, and protoporphyrin IX, which are all high-affinity ligands for MBR. Diazepam, a mixed MBR and central benzodiazepine receptor (CBR) ligand, 


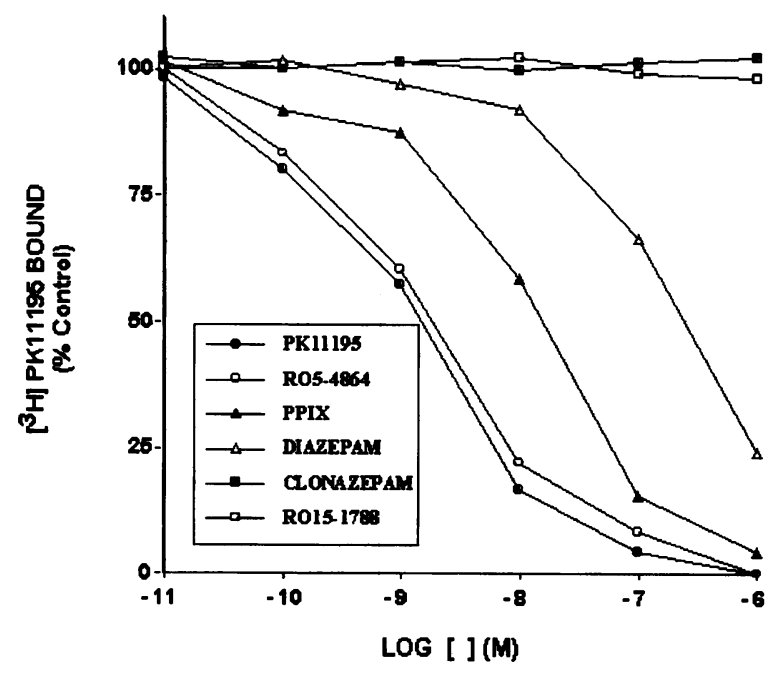

Fig. 1. Pharmacologic profile of $\left[{ }^{3} \mathrm{H}\right]$ PK11195 binding to V79 cell homogenates. Binding studies performed as described in Materials and Methods demonstrate the presence of MBR in V79 cells. Key for symbols: PK11195 (filled circles), R05-4864 (open circles), protoporphyrin (PP) IX (filled triangles), diazepam (open triangles), clonazepam (filled squares), R015-1788 (open squares).

showed intermediate inhibitory potency, whereas the CBR-specific ligands, clonazepam and R015-1788, were without effect (Fig. 1).

$\left[{ }^{3} \mathrm{H}\right]$ PK1 1195 binding to V79 homogenates was also potently inhibited by Photofrin II, a clinically employed tumor photosensitizing dye (largely composed of di-hematoporphyrin ether), but not by three other nonporphyrin phototoxic dyes-rhodamine 6G (21), rhodamine 123 (22), and merocyanine (23) (Fig. 2). Photofrin II also inhibited [ $\left.{ }^{3} \mathrm{H}\right]$ PK1 1195 binding to live V79 cells (Fig. 2). Similar $K_{i}$ values for Photofrin II were found for rat kidney mitochondria (Table 1) and other cell lines (data not shown). In a series of 27 porphyrin derivatives, relative potencies in eliciting photodynamic cell toxicity in the V79 cells correlated very closely with their affinities for MBR $(p<0.001)$.

If PDT involves MBR, then tumor cell lines with higher densities of MBR should be more sensitive. We evaluated the sensitivity to porphyrin photodynamic toxicity in 8 cell lines (Table 2 ). The relative sensitivity closely paralleled MBR density in these cell lines.

\section{Discussion}

Our most striking findings are two strong correlations that together implicate MBR as playing a

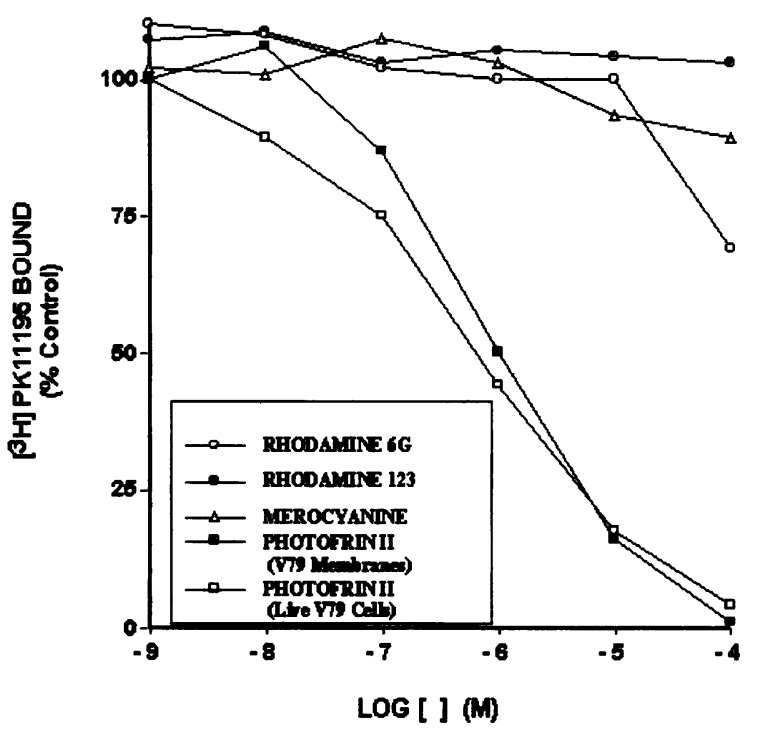

Fig. 2. Inhibition of $\left[{ }^{3} \mathrm{H}\right]$ PK11 195 binding to V79 cell homogenates and live cells (Photofrin only) by photosensitive dyes. Binding studies performed as described in Materials and Methods demonstrate the selective interaction of the porphyrin phototoxic dye, Photofrin II, with MBR in homogenized and live V79 cells. Key for symbols: rhodamine 6G (open circles), rhodamine 123 (filled circles), merocyanine (open triangles), Photofrin II with V79 homogenates (filled squares), Photofrin II with live V79 cells (open squares).

major role in PDT. First, we observed a close correlation between the potencies of porphyrins to catalyze cellular phototoxicity and their affinity for MBR, establishing a structure-activity profile for porphyrins and porphyrin-like compounds to mediate phototoxicity. Second, we observed that MBR density in tumors parallels their susceptibility to porphyrin-catalyzed phototoxicity. Such data suggest that mitochondrial damage is the proximal event that leads to observed cell death. This conclusion is supported by recent studies by Munday et al. (24), who show that mammalian cells deficient in mitochondria are refractory to porphyrin-catalyzed phototoxicity.

How might MBR mediate PDT? MBR comprises a complex of proteins apparently located at junctional sites of outer and inner membrane of mitochondria $(11,12)$. A molecular complex with such a localization could influence transactions between cytosolic and mitochondrial compartments. For example, hexokinase partitions from cytosol onto the outer mitochondrial surface where it binds to VDAC $(25,26)$. Interactions of VDAC with the inner membrane adenine nucleotide carrier may afford a path for exchange of 
Table 1. Relationship of porphyrin phototoxicity and MBR affinity

\begin{tabular}{|c|c|c|}
\hline Porphyrin & $\underset{(\mathbf{n M})}{\operatorname{MBR} \mathbf{K}_{\mathbf{i}}}$ & $\begin{array}{l}\text { D37 } \\
\text { (nM) }\end{array}$ \\
\hline "Neutral" porphyrin & 14 & 20 \\
\hline Protoporphyrin IX & 20 & 60 \\
\hline Mesoporphyrin IX & 40 & 50 \\
\hline Deuteroporphyrin IX & 50 & 60 \\
\hline Fe-Protoporphyrin IX (heme) & 50 & $>32,000$ \\
\hline$N$-methyl mesoporphyrin IX & 90 & 350 \\
\hline$N$-methyl protoporphyrin IX & 95 & 400 \\
\hline $\begin{array}{l}\text { 2,4(4,2)Hydroxyethylvinyl- } \\
\text { deuteroporphyrin IX }\end{array}$ & 100 & 125 \\
\hline Photofrin II & 100 & 153 \\
\hline Hematoporphyrin IX & 350 & 1,000 \\
\hline Zn protoporphyrin IX & 375 & 800 \\
\hline Chlorine E6 & 500 & 1,000 \\
\hline Diaspartylprotoporphyrin IX & 545 & 480 \\
\hline $\begin{array}{l}\text { 2-vinyl,4-hydroxymethyl- } \\
\text { deuteroporphyrin IX }\end{array}$ & 900 & 1650 \\
\hline Ditaurylmesoporphyrin IX & 1,000 & 350 \\
\hline Sn-protoporphyrin IX & 2,000 & 12,000 \\
\hline Coproporphyrin III & 2,500 & $>10,000$ \\
\hline Biliverdin & 2,500 & $>2,500$ \\
\hline Coprotoporphyrin IX & 5,000 & 8,000 \\
\hline Diglutamatylmesoporphyrin IX & 7,600 & 2,400 \\
\hline Hexaporphyrin & 24,000 & $>10,000$ \\
\hline Coproporphyrin I & 100,000 & $>10,000$ \\
\hline Pentaporphyrin & $>100,000$ & $>10,000$ \\
\hline Heptaporphyrin & $>100,000$ & $>10,000$ \\
\hline Bilirubin & $>100,000$ & $>2,500$ \\
\hline $\begin{array}{l}\text { Deuteroporphyrin IX } \\
\text { disulfonate }\end{array}$ & $>100,000$ & $>10,000$ \\
\hline $\begin{array}{l}\text { Deuteroporphyrin IX } \\
\text { BBGlycol }\end{array}$ & $>100,000$ & $>10,000$ \\
\hline
\end{tabular}

MBR $\mathrm{K}_{\mathrm{i}}$ values for porphyrins and analogs were determined by displacement of $\left.{ }^{3} \mathrm{H}\right]$ PK11195 binding to rat kidney mitochondria as described. Phototoxicity studies using V79 Chinese hamster lung cells were performed as described in Materials and Methods. D37 values represent doses that reduce survival to $37 \%$ of control. $\mathrm{K}_{\mathrm{i}}$ values are the inhibitory constants of drugs for MBR. As FeProtoporphyrin IX (heme), a potent MBR ligand is not a photosensitive molecule, it does not cause phototoxicity. With the omission of heme, the $\mathrm{D}_{37}$ and $\mathrm{MBR} \mathrm{K}_{\mathrm{i}}$ values correlate with a coefficient of 0.827 $(p<0.001)$. Experiments were performed three times in duplicate and results shown are mean values.

mitochondrial ATP with ADP generated by hexokinase (26). This would provide direct ATP supply to hexokinase and yield improved mitochondrial coupling through kinase-generated ADP. Tumor cells display especially high levels of hex-
Table 2. Relationship of MBR density and PDT susceptibility in cell lines

\begin{tabular}{lll}
\hline Cell Type & MBR Density & PDT Sensitivity \\
\hline Mouse L & ++++ & ++++ \\
C $_{6}$ glioma & +++ & +++ \\
V79 & +++ & +++ \\
HepG $_{2}$ & ++ & ++ \\
Hela & ++ & ++ \\
SVEC 4-10 & ++ & ++ \\
WiDR & + & + \\
LS174T & + & +
\end{tabular}

MBR density was determined as described in Materials and Methods. $K_{d}$ and $B_{\max }$ values for each cell line were: mouse $\mathrm{L}=1.3 \mathrm{nM}, 5.5 \mathrm{pmol} / \mathrm{mg} ; \mathrm{C}_{6}$ glioma $=1.5 \mathrm{nM}, 4.2$ $\mathrm{pmol} / \mathrm{mg} ; \mathrm{V} 79=1.2 \mathrm{nM}, 3.9 \mathrm{pmol} / \mathrm{mg} ; \mathrm{Hela}=1.9 \mathrm{nM}, 95$ $\mathrm{pmol} / \mathrm{mg}$; Hep $\mathrm{G}_{2}=1.85 \mathrm{nM}, 1.9 \mathrm{pmol} / \mathrm{mg}$, SVEC $4-10=$ $1.8 \mathrm{nM}, 1.7 \mathrm{pmol} / \mathrm{mg}$; WiDR $=1.5 \mathrm{nM}, 0.75 \mathrm{pmol} / \mathrm{mg}$; LSI94T $=1.3 \mathrm{nM}, 0.9 \mathrm{pmol} / \mathrm{mg}$. PDT sensitivity and cell survival were assessed as described in Materials and Methods. Concentrations of Photofrin II producing 10\% survival versus control (Photofrin II without light) for the lines were $(\mu \mathrm{g} / \mathrm{ml})$ mouse $L=0.37 ; \mathrm{V79}=0.50 ; \mathrm{C}_{6}$ glioma $=$ $0.57 ; \mathrm{HepG}_{2}=0.71$; Hela $=0.75 ;$ SVEC 4-10 $=0.77$;

WiDR $=0.92 ; \mathrm{LS} 174 \mathrm{~T}=0.88$. Scoring system for this table was as follows: $++++=B_{\max }>5 \mathrm{pmol} / \mathrm{mg}$ protein, $10 \%$ survival dose $<0.4 \mu \mathrm{g} / \mathrm{ml} ;+++=\mathrm{B}_{\max } 2-5 \mathrm{pmol} / \mathrm{mg}$ protein, $10 \%$ survival dose $0.4-0.6 \mu \mathrm{g} / \mathrm{ml} ;++=\mathrm{B}_{\max } 1-2$ $\mathrm{pmol} / \mathrm{mg}$ protein, $10 \%$ survival dose $0.6-0.8 \mu \mathrm{g} / \mathrm{ml} ;+=$ $\mathrm{B}_{\max }<1 \mathrm{pmol} / \mathrm{mg}$ protein, $10 \%$ survival dose $>0.8 \mu \mathrm{g} / \mathrm{ml}$. Results are means of two experiments performed in duplicate.

okinase attached to mitochondria (25-27), which might account for the high rate of "aerobic glycolysis" seen in many neoplastic cells. Porphyrin photooxidation of MBR-associated VDAC or adenine nucleotide carrier could thus profoundly affect tumor bioenergetics.

Recent findings have implicated MBR in the transport of porphyrins in and out of mitochondria (28). Porphyrins used in photodynamic therapy may thus enter cells and accumulate on mitochondrial porphyrin transport sites. Porphyrins with the highest affinity for MBR would be expected to accumulate the most in this manner. This may explain the suggested role of MBR in delta-aminolevulinic acid (ALA)-mediated phototoxicity in pancreatoma cells (29), as ALA phototoxicity requires conversion to protoporphyrin IX prior to its phototoxic effects.

The ability of MBR to modulate ion conductances (30) and cholesterol movement across mitochondrial membranes (31) implies a substan- 
tial role for $M B R$ in regulating mitochondrial compartmentation. Thus, the adenine nucleotide carrier is believed to mediate the nonspecific increase in mitochondrial inner membrane permeability observed after $\mathrm{Ca}^{2+}$ overloading and oxidative injury to mitochondria (32). This protein is labeled by the alkylating benzodiazepine $\left[{ }^{3} \mathrm{H}\right]$ AHN086 (11) which causes a large release of calcium from isolated mitochondria (33). We hypothesize that porphyrins, when bound to MBR and exposed to light, generate radical oxygen species that oxidize the adenine nucleotide carrier to increase mitochondrial permeability. This would account for the rapid loss of adenine nucleotide exchange and $\mathrm{Ca}^{2+}$ release from mitochondria following porphyrin PDT $(9,20,34)$ and associated cytotoxicity. The oxidative sensitivity displayed by the adenine nucleotide carrier (35) supports our hypothesis and indeed may implicate the MBR complex in diverse pathological and physiological phenomena.

Our findings have clear clinical relevance. Some benzodiazepines and related agents have extremely high affinity for MBR in the low nanomolar range and, like porphyrins (36), radiolabeled forms of these agents have been employed to localize neoplasms in vivo (37). Photosensitive compounds with high affinity for MBR may afford more specific PDT agents with fewer side effects. Such compounds may also be readily screened for using binding studies with $\left[{ }^{3} \mathrm{H}\right]$ PK11195 and isolated mitochondria. Interestingly, MBR levels are increased in several types of tumors $(38,39,40)$.

\section{Acknowledgments}

This work was supported by USPHS grant DA00266, Research Scientist Award DA-00074 to S.H.S., ES-07076 to J.R.W., and a grant of the W.M. Keck Foundation (S.H.S.). A.V. was supported by a grant from The Defense and Veterans Head Injury Program.

\section{References}

1. Spikes JD, Jori L. (1987) Photodynamic therapy of tumors and other diseases using porphyrins. Lasers Med. Sd. 2:3-15.

2. Moan J. (1988) Porphyrin photosensitization and phototherapy. Photochem. Photobiol. 6:681-690.

3. Brown SB, Kessel D. (1990) Cancer and porphyrin photochemotherapy. Mol. Aspects Med. 11:99-111.

4. Pass HI. (1993) Photodynamic therapy in oncol- ogy: mechanisms and clinical use. J. Natl. Cancer Inst. 85:443-456.

5. Berns SB, Dahlman A, Johnson FM, et al. (1982) In vitro cellular effects of hematoporphyrin derivative. Cancer Res. 42: 2325-2329.

6. Roberts WG, Berns MW. (1989) In vitro photosensitization I. Cellular uptake and subcellular localization of mono-L-aspartyl chlorine ${ }_{6}$, chloro-aluminum sulfonated phthalocyanine, and Photofrin II. Lasers Surg. Med. 9:90-101.

7. Perlin DS, Murant RS, Gibson SL, Hilf R. (1985) Effects of photosensitization by hematoporphyrin derivative on mitochondrial adenosine triphosphate-mediated proton transport and membrane integrity of R3230AC mammary adenocarcinoma. Cancer Res. 45:653-658.

8. Hilf R, Murant RS, Narayanan V, Gibson SL. (1986) Relationship of mitochondrial function and cellular adenosine triphosphate levels to hematoporphyrin derivative-induced photosensitization in R3230AC mammary tumors. Cancer Res. 46:211-217.

9. Salet C. (1986) Hematoporphyrin and hematoporphyrin-derivative photosensitization of mitochondria. Biochemie 68:865-866.

10. Krueger KE. (1991) Peripheral type benzodiazepine receptors: A second site of action for benzodiazepines. Neuropharmacology 4:1417-1423.

11. Verma A, Snyder SH. (1989) Peripheral type benzodiazepine receptors. Annu. Rev. Pharmacol. Toxicol. 29:307-322.

12. McEnery MW, Snowman AM, Trifiletti RR, Snyder SH. (1992) Isolation of the mitochondrial benzodiazepine receptor: Association with the voltage-dependent anion channel and the adenine nucleotide carrier. Proc. Natl. Acad. Sci. U.S.A. 89: 3170-3174.

13. Krueger KE, Mukhin AG, Antkiewicz-Michaluk L, et al. (1990) Purification, cloning and expression of a peripheral type benzodiazepine receptor. $A d v$. Biochem. 46:1-13.

14. Doble A, Burgevin MC, Meager J, et al. (1987) Partial purification and pharmacology of peripheral type benzodiazepine receptors. J. Recept. Res. 7:55-70.

15. Verma A, Nye JS, Snyder SH. (1987) Porphyrins are endogenous ligands for the mitochondrial (peripheral type) benzodiazepine receptor. Proc. Natl. Acad. Sci. U.S.A. 84: 2256-2260.

16. Verma A, Snyder SH. (1988) Characterization of porphyrin interactions with peripheral-type benzodiazepine receptors. Mol. Pharmacol. 34:800-805.

17. Cantoni L, Rizzardini M, Skorupska M, et al. (1992) Hepatic protoporphyria is associated with a decrease in ligand binding for the mitochondrial benzodiazepine receptors in the liver. Biochem. Pharmacol. 44:1159-1164.

18. Hilf R, Warne NW, Smail DB, Gibson SL. (1984) Photodynamic inactivation of selected intracellular enzymes by hematoporphyrin derivatives and 
their relationship to tumor cell viability in vitro. Cancer Lett. 24: 165-172.

19. Yamamoto K, Kawanishi S. (1991) Oxidation of specific S4 protein of mitochondria by photodynamic action of hematoporphyrin. Biochem. Pharmacol. 42:1087-1092.

20. Atlante A, Passarella S, Quagliariello E, Moreno G, Salet C. (1989) Hematoporphyrin derivative (Photofrin II) photosensitization of isolated mitochondria: Inhibition of ADP/ATP translocator. J. Photochem. Photobiol. 4:35-46.

21. Saetzler RK, Jallo J, Lehr HA, Phillips CM, Vasthare U, Arfors KE, Tuma RF. (1997) Intravital fluorescence microscopy: Impact of light-induced phototoxicity on adhesion of fluorescently labeled leukocytes. J. Histochem. Cytochem. 45:505-513.

22. Shea CR, Sherwood ME, Flotte TJ, Chen N, Scholz M, Hasan T. (1990) Rhodamine 123 phototoxicity in laser-irradiated MGH-Ul human carcinoma cells studied in vitro by electron microscopy and confocal laser scanning microscopy. Cancer Res. 50:4167-4172.

23. Gulliya KS, Matthews JL, Fay JK, Dowben RM. (1988) Increased survival of normal cells during laser photodynamic therapy: implications for ex vivo autologous bone marrow purging. Life Sci. 42:2651-2656.

24. Munday AD, Sriratana A, Hill JS, Kahl SB, Nagley P. (1996) Mitochondria are the functional intracellular target for a photosensitizing boronated porphyrin. Biochem. Biophys. Acta 1411:1-4.

25. Fiek C, Benz R, Roos N, Brdiczka D. (1982) Evidence for identity between the hexokinase-binding protein and the mitochondrial porin in the outer membrane of rat-liver mitochondria. Biochim. Biophys. Acta 688:429-440.

26. Nelson BD, Kabir F. (1986) The role of the mitochondrial outer membrane in energy metabolism of tumor cells. Biochemie 68:407-415.

27. Nakashima RA, Scott LJ, Pedersen PL. (1986) The role of mitochondrial hexokinase binding in the abnormal energy metabolism of tumor cell lines. Ann. N. Y. Acad. Sci. 488:438-450.

28. Taketani S, Kohno H, Furukawa T, Tokunaga R. (1995) Involvement of peripheral-type benzodiazepine receptors in the intracellular transport of heme and porphyrins. J. Biochem. 117:875-880.

29. Ratcliffe SL, Matthews EK. (1995) Modification of the photodynamic action of delta-aminolaevulinic acid (ALA) on rat pancreatoma cells by mitochon- drial benzodiazepine receptor ligands. $B r$. J. Cancer 71:300-305.

30. Kinnally KW, Zorov DB, Antonenk YN, Snyder SH, McEnery MW, Tedeschi H. (1993) Mitochondrial benzodiazepine receptor linked to inner membrane ion channels by nanomolar actions of ligands. Proc. Natl. Acad. Sci. U.S.A. 90:1374-1348.

31. Krueger KE, Papadopolous V. (1990) Peripheraltype benzodiazepine receptors mediate translocation of cholesterol from outer to inner mitochondrial membranes in adrenocortical cells. J. Biol. Chem. 265:15015-15022.

32. LeQuoc K, LeQuoc D. (1988) Involvement of the ADP/ATP carrier in calcium-induced perturbation of the mitochondrial inner membrane permeability: Importance of the orientation of the nucleotide binding sites. Arch. Biochem. 265:249-257.

33. Moreno SR, Brako C, Gutierrez J, Newman AH, Chiang PK. (1991) Release of $\mathrm{Ca}^{2+}$ from heart and kidney mitochondria by peripheral-type benzodiazepine receptor ligands. Int. J. Biochem. 23:207213.

34. Salet C, Moreno G, Vinzens F. (1983) Effects of photodynamic action on energy coupling of $\mathrm{Ca}^{2+}$ uptake in liver mitochondria. Biochem. Biophys. Res. Commun. 115:76-81.

35. Zwizinski CW, Hho S. (1992) Peroxidative damage to cardiac mitochondria; Identification and purification of modified adenine nucleotide translocase. Arch. Biochem. Biophys. 294:178-183.

36. Hill JS, Kohl SB, Kaye AH, et al. (1992) Selective tumor uptake of a boronated porphyrin in an animal model of cerebral glioma. Proc. Natl. Acad. Sci. U.S.A. 89:1785-1789.

37. Starosta-Rabinstein S, Ciliax BJ, Penney JB, McKeever P, Young AB. (1987) Imaging of a glioma using peripheral benzodiazepine receptor ligands. Proc. Natl. Acad. Sci. U.S.A. 84:891-895.

38. Katz Y, Ben-Baruch G, Kloog Y, Menczer J, and Gavish M. (1990) Increased density of peripheral benzodiazepine-binding sites in ovarian carcinomas as compared with benign ovarian tumours and normal ovaries. Clin. Sci. (Colch.) 78:155-158.

39. Katz Y, Eitan A, and Gavish M. (1990) Increase in peripheral benzodiazepine binding sites in colonic adenocarcinoma. Oncology 47:139-142.

40. Batra S, and Alenfall J. (1994) Characterization of peripheral benzodiazepine receptors in rat prostatic adenocarcinoma. Prostate 24:269-278. 